\title{
Health Care in Greece and the Netherlands in the Nineteenth Century. A Tale of Two Cities
}

Pim Kooij and Lydia Sapounaki-Dracaki

\section{Summary}

In the nineteenth century legislation concerning health care in Greece did not differ from that in the Netherlands, derived as it was from the French example in both cases. This article contains a comparison of the organisation and the effects of (public) health care in the Dutch city of Groningen and the Greek city of Piraeus, cities which in the course of the nineteenth century reached about the same size. It shows that on the local level, in spite of the convergence in national legislation, there were large differences in the way (public) health care was distributed and in the acceptation by the public. This was for example reflected in different death ratios.

\section{Introduction}

Both Greece and the Netherlands became national states at the beginning of the nineteenth century. Before that time the Netherlands had been a federal republic of seven provinces, while Greece had been occupied by the Turks for centuries. Each nation adopted a monarchy. As is usually the case in such circumstances, the monarchs and the central governments of both countries initiated legislation to promote unity in their countries. Health care was one of the domains in which new laws were promulgated. In Greece health care was organised by the Ministry of the Interior, which created a special branch

* We are grateful to the editors and the anonymous referees for their helpful suggestions.

Prof. Dr Pim Kooij, Department of History, Groningen University, Postbox 716, NL-9700 AS Groningen (p.kooij@let.rug.nl).

Dr Lydia Sapounaki-Dracaki, Department of Economics and Regional Development, Panteion University Athens, 136 Sygrou Avenue, GR-17671 Athens (ldracaki@panteion.gr). 
called the Sanitary Department. This department enacted special measures for the prevention of 'outside threats': Health Offices, Health Guard Houses and lazarettos were founded, as well as Centres for Contagious Diseases in those parts of the country where epidemics were most likely to occur.

The Health Department was also responsible for hygiene in cities, towns and villages, where the municipalities had the supervision of the water supply, street cleaning, the quality of the food, markets, slaughterhouses, sewers and cemeteries. In these matters the municipal authorities were assisted by the municipal police and municipal doctors, the latter ensuring compliance with the health regulations. The municipal doctors at that time were often eminent members of local society and scholars. They generally used their practice in the municipality to add prestige to their prodigious CVs and to bolster their private practices. Therefore they only required a small fee from the municipality or sometimes worked free of charge ${ }^{1}$. A salaried municipal doctor coordinated the health services the municipality provided and reported to the mayor and the members of the municipal council.

On a higher level, prefectures were responsible for health matters together with the doctors and inoculators of the prefectures. In the 1850s the doctors working in the subprefectures had responsibility for these matters. Very often the positions of the doctors employed in prefectures or suburbs remained vacant. In Greek cities and villages the majority of the municipal doctors without receiving a considerable salary were assisting the mayors and the police in their duties concerning public health ${ }^{2}$. In the Netherlands the supervision of health care had been organised into four hierarchical levels during the French occupation: at the local level commissions consisting mainly of doctors had to advise the municipality about public health matters. They were accountable to the provincial commissions, which in their turn were accountable to national inspectors who were controlled by the Ministry of the Interior. There was a lot of congruency between the juridical organisation of the responsibilities for health care, in spite of the differences in the level of development and modernisation in each country. This was caused by the fact that the Greek legislation had been transplanted from Bavaria by King Otto. Furthermore, both the Dutch and the Bavarian legislation had been influenced by the centralising French measures of the Napoleonic era.

1 For example the municipal doctors G. Lelis and later Th. Afentoulis, director of the hospital. Lelis was the first who used arguments in order to convey his ideas concerning public health and the need to create a public hospital for the health care of the population, Hronografos, 1954. A similar situation existed in France where the municipal doctors were characterised as 'cumulards', Dumons/Pollet/Saunier 1998, 193.

2 Flogaitis 1890, 465. 
In the Netherlands and in Greece the actual medical care was left to the municipalities. Already by the time of the Dutch Republic this sort of matter was regulated on the local and provincial levels. Central government contented itself with controlling these matters. This was cheaper and caused less trouble. In Greece the newborn state was unable to accomplish its new role and this led to the empowerment of the municipalities that were taking charge of all public matters concerning health, education and so on during the 19 th century3.

In the Netherlands, however, there was one exception. The status of doctors was precisely regulated during the first half of the nineteenth century. Even during the Ancien Régime, the 'doctores medicinae' in most cities had gained a dominant position over surgeons, midwives and other medical practicioners ${ }^{4}$. The abolition of the guilds created a need for a new juridical organisation of the medical professions. The 'doctores medicinae' succeeded in keeping their high status (for instance by a law of 1838) though their education was strictly theoretical and their methods of curing people were generally phrased in Latin aphorisms. Nevertheless, they were the only ones who were qualified to advise the authorities.

In Greece the medical profession was regulated at about the same time. A set of decrees concerned the control of empirical surgeons, pharmacists and midwives who had been practising their professions since the Turkish occupation, using dangerous methods and overcharging patients 5 . A Medical Board would give the licence to practise to doctors who had taken an examination. The empirical practitioners were allowed to practise under some conditions since their presence was essential for the health of the population. A medical-surgical school was founded, which operated until the establishment of the medical school of the University of Athens in 1837. In Greece in 1837,85 qualified doctors were practising alongside 130 government-licensed empirical doctors 6 .

After King Otto had been deposed, and until the First World War, health legislation became inactive. Therefore, during that period only a few laws were passed, and many others became invalid. From 1859 to 1908 the health budget became an increasingly smaller percentage of the national budget. At the same time, intensive urbanisation created serious health problems in the larger cities. The municipalities, therefore, had to take initiatives.

3 Sapounaki-Dracaki 1999, 25-26.

4 Querido 1965.

5 Kousis 1947, 60-64.

6 Kousis 1927, 4. 
As a result, in Greece as well as in the Netherlands, during the second half of the nineteenth century the juridical framework was offered and sustained by central government. The actual care, however, had to be provided by the municipalities. Since the framework in both countries was more or less the same, it is interesting to examine how health care was exercised on a local level in the two countries, which were at different stages of modernisation. Since the Netherlands had a long tradition of local and regional public health care, which was now covered by central government, whereas Greece had no tradition at all, we would expect the urban societies in the Netherlands to be more receptive to new developments in medicine.

In this article we will investigate the problems mentioned above on a municipal scale. This means that we will in the first place pivot on aspects of public health. Many definitions of public health exist. The most accepted define public health as a set of community services aimed at preventing illness ${ }^{7}$. Sometimes however, especially when medical historical research is performed in an urban setting, public health is described as a range of services provided by the government to promote health ${ }^{8}$. This definition not only covers preventive health care but also curative health care as far as it is offered by the (local) government, for instance in municipal hospitals. In this article we will refer to different hospitals (municipal, state, etc.), but we will not mention the housing conditions or other factors that influence public health in a broader sense.

Our research concerns two cities: Groningen in the Netherlands, and Piraeus in Greece. Groningen was rather peripherally situated in the north of the Netherlands. By the end of the Middle Ages it had become the economic capital of the Province of Groningen - of which it is also the political capital - and parts of the adjacent provinces of Friesland and Drenthe ${ }^{9}$. At that time the city already had 20000 inhabitants. In 1614 a university was founded. For a long period growth was halted and the number of inhabitants remained essentially the same. In the course of the nineteenth century, however, growth resumed and in the last quarter of the nineteenth century its population almost doubled (table 1 ). This was caused by the foundation of new industries - food, printing, bicycles, ready-made clothing - and by the extension of the service sector - grain trade, banking, insurance, retail

7 'Public health is concerned with defining the problems facing communities in the prevention of illness and thus studies of disease aetiology and promotion of health. It covers the investigation, promotion, and evaluation of optimal health services to communities ...' Holland/Detels/Knox (eds) 1984, preface.

8 See for instance Powel 1995.

9 Kooij 1987, 37-69. 
$\operatorname{trade}^{10}$. The city assumed extended functions as a harbour for its region. In 1876 a new canal to the sea was opened and a new port was constructed.

Piraeus, once the most important harbour near Athens, had almost disappeared during the Turkish occupation. It was only at the end of the nineteenth century that this city recovered. The first urban function of Piraeus was the commercial and it led to the financial and demographic development of the city. During the following decades, the newly established industry was based upon the commercial capital of the first citizens and covered their increased needs. During the period 1865-1875 the most important industries were textiles, the food industries and spirits. In 1888 Piraeus was the biggest industrial and commercial centre of the country. By the end of the century, the rapid development of Piraeus's dock led to the establishment of shipyards. Two important factors helped the development of the local economy; the expansion of the railway network and the construction of the Corinth Canal ${ }^{11}$.

At first sight those cities seem hardly comparable. Nevertheless, there are some similarities. Both cities had a commercial base and developed an industrial character. Moreover, both cities started to grow fast in the nineteenth century, especially by the immigration of low-income groups, attracted by the industries.

Table 1. The populations of the municipalities of Groningen and Piraeus in the 19 th century.

\begin{tabular}{lll}
\hline & Groningen & Piraeus \\
\hline 1807 & 26245 & - \\
\hline 1850 & 33694 & 5286 \\
\hline 1870 & 38528 & 11047 \\
\hline 1890 & 56038 & 34569 \\
\hline 1907 & 73278 & 74580 \\
\hline
\end{tabular}

Sources: The Netherlands: Censuses. Greece: Chouliarakis 1974, 1, 38, 50, 109.

Thus to a certain degree both cities shared the character of a boomtown. Therefore, the municipal authorities of both Greece and the Netherlands had to cope with similar problems concerning the fields of housing and public health care. We shall now examine the different ways in which each city tried to achieve this. We are especially interested in the similarities and differences of the measures taken in both cities in the field of health care and the way

10 Kooij 1994, 50.

11 Agriantoni 1999; Kalamitsis 1960; cf. Tsokopoulos 1984. 
they worked out. In this respect, we will use as an indicator the differentiation in the death rates, like Vögele did in his comparative study on British and German cities ${ }^{12}$.

The history of mortality decline demonstrates that improvements in health and changes in the social life of the general population can be achieved by the establishment of an effective local government ${ }^{13}$. In 1907 Piraeus and Groningen were both medium-size cities that were experiencing commercial and industrial activities ${ }^{14}$. The population growth and overcrowding led to urban problems that were threatening public health. This paper will examine the different measures and policies that each city applied in the field of health care and their influence on mortality. We will try to identify the mechanisms that led to differences in mortality rates through the examination of the municipal policy in the field of health care and provide information about the mortality decline in the two cities, hoping to lay the groundwork for further research.

\section{The tale of Groningen}

\section{Doctors, the Municipal Council, the University}

In 1876 a law was promulgated which exclusively confined the education of doctors to the universities. This marked the completion of a process of professionalisation, which had already begun during the Ancien Régime. In fact, the integration of the medical professions had mainly occurred during the first half of the nineteenth century. At that time the academic 'doctores medicinae' had a high status, but lacked the practical skills of the surgeons and midwives, which were more appreciated by the public ${ }^{15}$. Therefore a growing number of 'doctores medicinae' tried to obtain additional qualifications at the Nosocomium Clinicum (founded in 1797) and the local clinical school for surgeons and obstetrics (founded in 1823). In addition, some surgeons, in order to rid themselves of the doctores' control, went to the universities to obtain a degree. Table 2 shows that in the course of the nineteenth century the 'single' doctors became rare and that after 1876 the modern doctors took over medical care.

12 Vögele 1998.

13 See Szreter 1988, 37.

14 About classification of cities, see for instance Hietala 1987, 91.

15 Huisman 1992, ch. 15 and 18. 
After 1900 there was a rapid increase in the number of doctors/specialists, especially in surgery, E.N.T., ophthalmology, internal medicine and paediatrics. They were mainly employed in the Academic Hospital and in other hospitals in the city (see "Hospitals and ambulatory medical care"). In Groningen, as in other cities, the main victims of this process of professionalisation were the midwives. They were examined by the doctors and had to leave complicated deliveries to them. At an earlier stage the surgeons had successfully ousted barbers who practised bloodletting. The pharmacists were also strictly controlled by the local medical commission, but after 1876 pharmacy became an academic profession. Henceforward the pharmacists controlled their own branch ${ }^{16}$.

Table 2. Number of "doctors" in the city of Groningen.

\begin{tabular}{lrrrrrr}
\hline & 1818 & 1830 & 1850 & 1870 & 1890 & 1910 \\
\hline doctores medicinae & 9 & 13 & 7 & 4 & - & - \\
\hline doctores + extra qualifications & 3 & 2 & 13 & 15 & 7 & 1 \\
\hline surgeons & 4 & 4 & 4 & 4 & 2 & - \\
\hline qualified doctors & - & - & - & - & 16 & 30 \\
\hline specialists & - & - & - & - & - & 21 \\
\hline professors & 4 & 4 & 4 & 2 & 5 & 8 \\
\hline number of inhabitants per doctor & 1422 & 1315 & 1203 & 1496 & 1880 & 1255 \\
\hline
\end{tabular}

Source: Provincial Almanacs; Baron/Kooij 1993, 68.

In spite of the strong 'esprit de corps' manifested by the doctors to the outside world, there were large differences inside this group. Most doctors had people from higher income groups as their patients. In 1870 there were only two doctors for the poor. They were paid by the municipal government and had about $60 \%$ of the population as a potential patient ${ }^{17}$. In 1871 the number of doctors for the poor was increased to four. These doctors continually pressed the Municipal Council to take measures. In general, these doctors for the poor and some of their colleagues belonged to a group of hygienists, doctors who promoted measures in the field of public hygiene ${ }^{18}$. At that time

16 Tuin/Venema 1982.

17 This estimation is based on a reconstruction of the social structure of Groningen. For 1870 a sample of 1:10 households was taken from the Groningen Register of Population, located in the Groningen Archives. With the help of the registers of a local poll tax (de hoofdelijke omslag), also stored in the Groningen Archives, the differences in wealth were traced, which could be clustered in a stratification containing six layers. The lowest layer consisted of the families which were considered too poor to be able to pay any tax (61.8\% of all households). See also Kooij 1987, table 9.

18 Houwaart 1991. 
the hygienists still believed in the theory of miasmas: diseases were caused by germs originating from a polluted environment. In all large cities, including Groningen, medical topographies were written by hygienists to indicate those streets and quarters where the living conditions were the worst ${ }^{19}$. And the municipal governments were pressed to clean these areas. In Groningen the group of hygienists was very prominent by the end of the nineteenth century.

Throughout the nineteenth century, the Municipal Council of Groningen was dominated by a local elite. Until 1851 the members were directly appointed by central government. After that year a number of electoral reforms took place which gradually increased the number of voters. Despite this change the members of the middle class who were entitled to vote were still choosing members of the elite as their representatives ${ }^{20}$. It was only after the reforms of 1896 that the first representative of the lowest strata was elected. This was a socialist who did indeed make efforts to incorporate the living conditions of the Groningen poor in the political agenda. The primary concern of the elite was to take care of themselves. As we shall mention further on, their policy in public health matters had an ad hoc character, induced by epidemics. Naturally they felt constantly threatened by the living conditions and the health situation of the lowest strata, who lived nearby in the small back streets and slums in the centre of the city, just behind the main streets and squares where the houses of the elite were situated.

Their solution for this problem was residential segregation. In 1874 the city was allowed to remove its ramparts. The Municipal Council planned a new residential area to the south of the city, where the soil was sandy. A quarter for labourers was situated on the much lower clay grounds to the east of the city.

In the nineteenth century there were always some doctors, even medical professors, who were members of the Municipal Council. They did not, however, take many initiatives. It seems as if they only used their seats to emphasise the importance of the medical profession. They spoke as specialists but at the same time gave themselves airs by considering that medical matters were too important to be left to politicians, which did not favour a systematic policy concerning public health ${ }^{21}$.

19 Stratingh 1858.

20 Kooij 1992, 104-106.

21 This statement, which indeed refers to professionalisation of the medical profession, is based on a content analysis of the minutes of the meetings of the Municipal Council (Groningen Archives) between 1870 and 1914. The same observations were found in the handwritten memoirs (Aanteekeningen) of W. J. Roelfsema who was a member of the Municipal Council from 1882 to 1918 (Groningen Archives, collection of handwritings). 
In 1876 Groningen University had fewer than 200 students. From being an international centre of knowledge in the seventeenth century, it had reverted to being a regional educational centre. Central government intended to close the institution, but due to the efforts of a new minister of the interior, originally from Groningen, the university was saved. This induced a new élan. Student numbers rose and many new buildings were established, including an Academic Hospital. Applied science became the core of the Medical Faculty and the Hospital, combined with high-quality nursing. As a result the trust in hospital care, as we will see below, greatly increased.

\section{Policy}

In the nineteenth century, the main catalysts for the public health policy of the Municipal Council were the epidemics, which equally threatened all social layers. The first one was very dramatic. In 1826 an epidemic broke out of what was later called 'the Groningen disease'. It was probably a combination of malaria and typhoid fever. Nearly $10 \%$ of the inhabitants died. The measures taken by the local government resembled the ones taken during the Ancien Régime against the plague: the isolation of the sick in hospitals and orphanages, the cleaning of the streets with bleach and vinegar, regulations to speed up burials and financial support for people from the lower and middle classes who were struck by the disease. Also, two additional municipal doctors were appointed and doctors from other places recruited. The city had to borrow 200000 guilders from central government to finance all this.

In the middle of the century there were a number of cholera epidemics, beginning in 1832, with peaks in 1849 and 1866 when 698 and 1051 people died, respectively. The measures taken by the Municipal Council were the same as in 1826. Over the course of time, once the coming of an epidemic was announced, the cleaning of the streets and public toilets was done in advance. Even some structural measures were taken: the construction of more public toilets in streets where the poor lived, the substitution of the open sewage system by a closed one and the reconstruction of the municipal refuse dump.

According to the liberal ideology of the time, the actual nursing of the sick was left to committees, which were subsidised by the elite and the Municipal Council. This form of philanthropy organised by the elite was induced by two motives: fear of contagious diseases and the possibility to civilise the lower strata. This nursing was left to well-instructed male nurses ${ }^{22}$. The largest small-

22 Baron/Kooij 1993, 87. 
pox epidemic took place in 1870/71. A relatively small number died. The curative activities in this case, too, mainly consisted of isolation. Smallpox is indicative of the level of medicalisation of the population of the city. By the beginning of the century some Groningen doctors were already promoting vaccination, but most inhabitants only asked for it when the epidemic had already broken out and one could get the vaccination for free.

In 1865, due to a reform of the health laws, the local Health Commissions were abolished to strengthen the grip of central government on health affairs. Most local doctors did not protest because admission to the doctors' market could now be regulated by local branches of the National Federation of Doctors. The hygienists, however, successfully promoted the creation of a local council. In this council the local members of the Provincial Council were united. The chairman of the Provincial Council was L. Ali Cohen, one of the best-known hygienists in the Netherlands, who had written many books and articles on the subject ${ }^{23}$. The secretary of the committee was S. Coronel who was also an important hygienist ${ }^{24}$. Nevertheless, neither the provincial nor the local council succeeded in breaking the ad hoc character of the local policy. Most of their advice was ignored ${ }^{25}$. The local council was mainly used by the Municipal Council to take action in periods of epidemics. They then received a small subsidy.

Therefore, the local council could not do more than simply check whether the national laws concerning health were being implemented in the city. An important law in this context was an environmental law (1875) which was designed to restrict pollution from firms. However, many members of the Municipal Council were themselves entrepreneurs and did not cooperate very much. The control of the quality of the food was another of the council's initiatives. They reported directly to the provincial health inspector. The council did not succeed in persuading the local government about the need for a water supply. The Municipal Council feared a large deficit in the exploitation and the elite had their own wells. Nevertheless, Groningen did get its water supply. In 1880 two doctors started a private company. When this proved to be lucrative, the municipality tried to take it over, but did not succeed till the beginning of the twentieth century. In 1886 the local council, frustrated by the lack of cooperation from the Municipal Council, disbanded

23 See for Ali Cohen: Houwaart 1991. He was an authority in the field of preventive health care. His most famous book was: Handboek voor openbare gezondheidsregeling en den geneeskundige politie (1872) (Handbook for public health care and medical inspection).

24 Bergink 1960. In 1867 Coronel had moved from Amsterdam to Leeuwarden, the capital of Friesland, he was a specialist in occupational diseases.

25 De Vereeniging ter Bevordering van de Volksgezondheid, 8e verslag, p. 10 (Groningen Archives). 
itself. Some of its tasks, such as disinfection and the controlling of food, had to be taken over by local government. Table 3 lists the incomes and expenditures for public health care for a number of benchmark years.

Table 3. The expenses of the Groningen Municipal Council concerning medical and hygienic care (in guilders).

\begin{tabular}{lrrrrr}
\hline & 1870 & 1880 & 1890 & 1900 & 1910 \\
\hline disinfection and subsidies health council & 1963 & 1221 & 1164 & 3674 & 3765 \\
\hline veterinarians and inspectors & 700 & 1000 & 1360 & 1313 & 3421 \\
\hline municipal school for midwives & 289 & 760 & 876 & 1052 & 3191 \\
\hline subsidy ophthalmic clinic & - & 800 & 800 & 1233 & 1400 \\
\hline exploitation academic hospital & 5800 & 10780 & 12390 & 13992 & 23941 \\
\hline medical care for the poor and insane & 24407 & 31868 & 46962 & 62710 & 86287 \\
\hline new hospital & - & - & 430 & 171986 & - \\
\hline total & 33159 & 46429 & 63982 & 255960 & 122005 \\
\hline percentage of the total budget & 4.6 & 3.2 & 3.6 & 12.0 & 2.8 \\
\hline revenues (subsidies from the state, etc.) & 22468 & 4156 & 7580 & 81426 & 48570 \\
\hline
\end{tabular}

Source: Municipal Accounts.

In most years the expenses were rather low. Around 1900, however, the municipality had to take out loans to finance the building of the new Academic Hospital. The expenses for garbage and faeces collection and the supply of water to the poor in this period took up 5-10\% of the municipal budget. Until the 1890s, however, the revenues in this sector exceeded the expenses because of the sale of garbage and faeces to the peat area east of the city for use as manure.

\section{Hospitals and ambulatory medical care}

The first hospitals in Groningen were founded at the end of the eighteenth century: a military hospital and a Nosocomium Academicum (1797) which was connected to the university. The primary aim of the latter hospital was to collect a number of interesting cases for the teaching of the professors. In 1820 a Municipal Hospital for the poor was opened with a capacity of about 25 beds. This was intended for those poor who could not be nursed at home or who had to be isolated because of a contagious disease ${ }^{26}$. In 1852 the Noso-

26 Tonckens 1954; Van der Woude/van der Schuit 1997. 
comium and the Municipal Hospital merged into an Academic Hospital with 124 beds. From that time on, the advantages of intramural medical care slowly became clear (isolation, antisepsis and asepsis). By 1863, 7\% of the patients were paying for themselves. The development of anaesthesia and the introduction of X-ray treatment (in 1899) also attracted people from the higher social strata. From 1870 on, plans for a new academic hospital were made by the three partners involved: the municipality, the province and the state (who financed the university). Initially the Municipal Council took the lead because they considered a new academic hospital to be a major argument against the closing of the university. When this threat had passed, the eagerness to invest diminished. The members of the elite did not need this hospital for themselves. They still preferred to be nursed at home. Moreover, in 1893 a Protestant Hospital had opened in the quarter of the town where the elite lived and in 1897 a Roman Catholic hospital followed ${ }^{27}$. They offered better accommodation.

Now the state had to become the main protagonist for a modern hospital. After years of negotiations an agreement was reached. The construction of the hospital was financed by the municipality and the province, but the greater part of the exploitation costs had to be paid by the state, which also had to refund $5 \%$ of the construction costs each year. The modern hospital, with a capacity of 390 beds and consisting of pavilions to minimise the spread of contagious diseases, was opened in 1903. It had special departments for members of the elite and the middle class. As a result the proportion of patients sent by the poor law administration fell dramatically. By 1910,35\% of the patients were paying for themselves, and the actual number of patients after 1903 rose very fast, from 1105 in 1900 to 2875 in $1910^{28}$. Nevertheless, well-to-do Groningen patients still preferred the denominational hospitals. Whereas in 1910 the ratio of poor:paying patients for the province of Groningen was $63: 37$, for the city it was $86.5: 13.5^{29}$.

The improvement in the curative possibilities of the hospital is indicated by the fact that some doctors sent their own children to the hospital to be treated by the professors. The Academic Hospital definitely lost its image as a place where people were bound to die. By 1900 only $15 \%$ of patients died in the hospital, and $75 \%$ were still alive one year after their dismissal ${ }^{30}$. Compared with other hospitals this percentage was not that low. The Coolsingel

27 Tammeling 1979; Tammeling 1987.

28 Archives Academic Hospital, Register of patients.

29 Archives Academic Hospital, Register of patients.

30 Conclusion based on a sample 1:10 from the Register of patients of the Academic Hospital, which was linked to the Death Registers (Groningen Archives). 
hospital in Rotterdam for instance, in 1900 had $10.8 \%$ deaths ${ }^{31}$. However, we have to keep in mind that the Groningen Academic Hospital together with the other academic hospitals formed the top of the hierarchy and got many 'difficult' patients, which could not be treated in other hospitals.

The Groningen poor law administration was very reluctant to send the poor to the hospital because of the cost. Regular care was offered to the poor by the municipal doctors. They were assisted by district nurses and had their own treatment rooms in the quarters of the city. Their form of medical care was well accepted by the lower strata citizens. In 1905 there were 4817 families and individuals, who were assisted by the poor law administration. Together they received 1180 tickets for free medical care. The tickets for free deliveries were also very popular ${ }^{32}$.

In 1908 a school doctor was appointed. This was very modern. In Brussels the first school doctor was appointed in 1874, in Paris in 1884 and in London in 1889 , whereas also many German cities had a school doctor. But in the Netherlands Groningen was the second city with a fully fledged school doctor, after Zaandam ${ }^{33}$. In his first year, the doctor together with nurses checked 8000 children; $10 \%$ of these children had a disease, among them 63 with tuberculosis, 16 having pertussis, 14 scarlet fever and 7 favus $^{34}$. An institution especially for the poor was the eye hospital, founded by a later professor of the university, which was subsidised by the Municipal Council, and in 1891 a wealthy entrepreneur, W. A. Scholten, founded a children's hospital, also primarily meant for the poor. These were the only examples of philanthropy in these matters in Groningen.

\section{Results}

As we have seen in the preceding subsection, the opportunities for medical care for the Groningen population seem to have been rather high around the turn of the century. This was particularly the case for the elite and the lowest strata. The middle classes had more difficulties in gaining access to medical care ${ }^{35}$. Sometimes they had to ask the doctors of the poor for free

31 Van Lieburg 1986.

32 Groningen Archives, Verslag van den toestand der gemeente Groningen, 1905, 167. In 1901 a free choice of midwives was abolished. In that year three municipal midwives were appointed.

33 Groningen Archives. Archives of the Municipality of Groningen, Letter to the Municipal Council of Groningen, 3. 10. 1904.

34 Groningen Archives, Verslag van den toestand der gemeente Groningen, 1908, appendix IJ.

35 In 1900 among the Groningen heads of households 3.2\% belonged to the elite and 4.1\% to the subelite. $28.1 \%$ of the heads of households belonged to the middle classes, and $64.7 \%$ to the working class, Kooij 1987, table 9. 
treatment but in many cases pride prevented them doing this. A growing number of the members of the middle class subscribed to a health insurance fund. The 'Algemeen Groninger Ziekenfonds' (General Groningen Health Insurance Fund) was founded in 1892. The number of members rose from 598 in 1892 to 2419 by 1900 . The subscription for a nuclear family was about $2 \%$ of the average salary of a middle class head of household.

Unfortunately there are no exact data on self-medication and treatment by non-qualified medical men. The advertisements in the newspapers, however, suggest that this form of medical care must have been considerable. Anyway, the qualified Groningen doctors now had to found a committee against quackery because of the reluctance of the liberal municipal government to control these practices as they had done during the Ancien Régime.

Table 4. Causes of death in Groningen (\%).

\begin{tabular}{lrrr}
\hline & $1867-1882$ & $1883-1899$ & $1899-1914$ \\
\hline contagious diseases & 10 & 7 & 8 \\
\hline tuberculosis & 12 & 14 & 13 \\
\hline cancer & 3 & 6 & 10 \\
\hline nervous system diseases & 9 & 10 & 9 \\
\hline heart and vascular diseases & 2 & 4 & 6 \\
\hline respiratory organs & 19 & 20 & 15 \\
\hline digestive organs & 14 & 12 & 11 \\
\hline urogenital organs & 3 & 5 & 5 \\
\hline pregnancy and childbirth & 1 & 1 & 1 \\
\hline stillbirth & 13 & 8 & 6 \\
\hline others and unknown & 14 & 13 & 16 \\
\hline $\mathrm{N}$ & 1292 & 1282 & 1357 \\
\hline
\end{tabular}

Source: Groningen Archives: Death registers and death certificates (sample 1:15). See also Kooij 1987, table 76.

It is not easy to fix the demographic effects of the improvements in local health care during the last quarter of the nineteenth century. There are some indications, however. In 1870-1875 the death rate was 28.2. In 1895-1900 this rate fell to 15.4. Examining the age of the deceased, we see that infant mortality was still rather high. In 1895-1900 31\% of the deceased were under 5 years of age (21\% under 1$)$. Yet, this was still about $10 \%$ lower than in around $1870^{36}$. In the Groningen municipal archives are the forms which had

36 Groningen Archives, Minutes of the Vereeniging ter bevordering van de Volksgezondheid; verslag van den toestand der gemeente Groningen; Statistics of deaths. 
to be filled in by the doctors when a patient had $\operatorname{died}^{37}$. This enables us to differentiate the causes of death. The rise in the average age of the deceased is illustrated by the rise in heart disease and cancer.

In the medical-historical literature four causes are mentioned for the fall in the death rate in general: improved medical care, curative as well as preventive; improvement in living conditions by public health measures; improved personal hygiene and a rising standard of living. The debate on which of these was dominant, which started in the 1960s with the interventions of Th. McKeown, is still going on ${ }^{38}$. All four factors were working in Groningen at that time. Three have already been mentioned. The fourth one was also manifest. Between 1870 and 1910 the average real income of the Groningen heads of households rose from 650 guilders to 930 guilders ${ }^{39}$. Though the hygienists claimed that measures in the field of public health reduced the death rate, the effects of the rise in real incomes, which allowed people to improve the quality of their food and housing, might have been more important. A strong argument for this point is that the number of victims of contagious diseases, as compared to the number of patients, fell dramatically. In around 1870 measles was the biggest killer of children ${ }^{40}$. Although no medicine had yet been found, in around 1900 only few children were dying of that disease.

\section{The tale of Piraeus}

\section{Doctors, the Municipal Council}

The first measures taken by the Medical Council concerned the practice of and studies for the medical and paramedical professions. From 1834 on scientific studies were obligatory for new members of the medical profession. Before the foundation of the School of Medicine of the University of Athens in 1837, doctors had studied at foreign universities, and since 1824 at the Ionian Academy of Corfu. In Athens there was also a temporary school of surgery used for doctors without degrees. In 1839 the first chair of pharmacy was created at the University of Athens. In 1838 a school for midwives was

37 Groningen Archives, Death forms.

38 See for a recent survey: Vögele 1998, ch. 2, and Anderson 1996, 249-254.

39 Kooij 1987, 300.

40 According to the annual accounts of the city of Groningen (Verslag van den toestand der gemeente Groningen) in 1885 there were 666 measles patients. 101 of them died. Ten years later only 21 out of 504 patients died. In 1895 the depression of the eighties had turned into a more prosperous period. See Van Zanden 1996. 
founded in Athens. The midwives were submitted to very strict legislation, for instance they had to be certified by committees of doctors from the region where they would practise. Following the examples of their colleagues abroad, doctors started to create professional institutions. In 1835 they founded the Medical Society of Athens, in 1866 the Society of Greek Doctors and in 1882 the Hygiene Society ${ }^{41}$.

The doctors of Piraeus belonged to the upper classes, especially the professors and the scientific managers of the hospitals, and they were appreciated by the local population. One example is Theodore Afendoulis, professor director of the Zanion Hospital and member of the Medical Association of Athens, created in 1835 (the Medical Association of Piraeus was founded in 1899). Doctors in Piraeus were also equal participating members of the Society of Hygiene. Through this association doctors gave their opinions and enforced their visions on public health ${ }^{42}$. Individual doctors in Piraeus did not formulate opinions on public health on their own but expressed them through committees to which they had been nominated by the Municipal Council. They offered their services to the poor and the wealthy alike without discrimination. At the beginning of the twentieth century a large number of doctors were practising in the city (table 5). As the table shows, this did not lead to an automatic improvement in the ratio of doctors in the city, because of the rapid growth of Piraeus. As a well-known doctor of that time informs us, in 1896 Piraeus had a ratio of one doctor per 1244 inhabitants, slightly below the national average of 1170 . It should not be overlooked that during the same period in neighbouring Athens there was one doctor per 491 inhabitants ${ }^{43}$.

Table 5. Number of doctors in the city of Piraeus.

\begin{tabular}{lrrrrr}
\hline & 1842 & 1861 & 1875 & 1881 & 1907 \\
\hline doctors & 3 & 5 & 12 & 18 & 55 \\
\hline number of inhabitants per doctor & 360 & 1253 & 1150 & 1726 & 1236 \\
\hline
\end{tabular}

Sources: HAMP, folder 1842 D.; Ministry of Interior 1862, 69; Kambouroglou 1883, 66; Mpoukas 1875, 8-8-89; cf. Alexakis 1906, 125-126.

Prior to the constitution of 1864 , the ten wealthiest members of society chose three members to be presented to the king for his selection of the mayor. In 1866 the members of the Municipal Council were elected

41 Korasidou 2002,140-156.

42 Mastroyannis 1960, 126-155; Rigatos 1991,39-44 and 106-110.

43 Foustanos provides statistics on the doctors of Greece in: Korasidou 2002, 155. 
democratically by the people. Nevertheless, these elected members primarily remained part of the elite until the end of the nineteenth century. They did not formulate a complete local health policy but only measures concerning epidemics and infrastructure. These measures were influenced by the interests of the bourgeoisie and by political factors, such as the role of the population in elections, firstly concerning the interests of the bourgeoisie and secondly for political reasons, concerning the population which represented the largest number of voters ${ }^{44}$.

\section{Policy}

In Piraeus, as in Victorian cities of the nineteenth century, health was viewed very much as a matter of lack of disease, the causes of which were linked with overpopulation, unhealthy conditions and poverty ${ }^{45}$. Piraeus in 1834 was completely unpopulated, but despite this, the Municipal Council played its economic and organisational role by creating the right conditions for settlement. Thus, the first settlers became the nucleus, which would elevate Piraeus to the status of a great commercial, industrial and maritime centre for the whole country and also the biggest port in the eastern Mediterranean Sea. The port was not only a development factor, it was often the main cause of contagious diseases. In 1854 the foreign crews spread cholera, in 1868 Cretan refugees brought smallpox that plagued the city for many years and peaked in 1874. In 1882/83 a worse epidemic of smallpox broke out which spread to other cities. In 1889 a fever that claimed 10000 victims started in Piraeus, as did the diphtheria epidemic of 1894. A smallpox epidemic struck again in the 1890s with disastrous results for the economy of the city since it drove away foreign ships ${ }^{46}$.

The problems were greater in the working class's neighbourhoods. There the houses were built on swampy grounds with no infrastructure and no consideration for hygiene, and the food was insufficient and of bad quality. In this industrial quarter of the city lived the largest number of the indigent population. Although issues regarding urban hygiene were discussed by the City Council, they were not considered to be priority issues. Priorities were city streets, gas lighting and the transportation of drinking water. In 1884, after a series of anti-flooding water projects and drainage works, public hygiene gained top priority in the agenda of the municipality. Despite the

44 Sapounaki-Dracaki 1986a, 27-32; Tsokopoulos 1984, 116-126.

45 Price/Blair 1989, 37.

46 Sphaira 1895c; Sphaira 1895d; Savas/Kousis 1930, 252-260. 
efforts made at the beginning of the twentieth century, rotten fruit floated in the port of Piraeus, sometimes the dirty water was not driven out to the sea and many open sites were covered by animal carcasses and excrement ${ }^{47}$.

The principal way of dealing with an epidemic was by the use of vaccination, which was compulsory and free of charge. The municipality covered the costs of vaccination for its citizens, and the government covered those same costs for foreigners. The indifference and ignorance of the public often drove the municipality to take police measures and to impose fines in order to encourage people to be vaccinated. The supply of vaccine was enough for smallpox due to local production and imports from France. During the great smallpox epidemic of 1895 , the city was divided into four areas each with a doctor appointed to vaccinate the poor for free. In December 1895, a new vaccine establishment was founded at Piraeus capable of producing 400 tubes per day. The municipality granted $8000 \mathrm{Dr}$ (about $£ 180$ ) to it on condition that it furnished 1000 tubes of vaccine every year for use in the public stations. Unlike the handling of smallpox, which followed the preventive methods of other European countries for 'new' diseases like rabies, methods were rather primitive, as mentioned by Consul Masxe: "A muzzling order does exist in Attica but it is not enforced, and the strewing of poisoned meat in the streets of Athens is apparently the only attempt made by the authorities to deal with increasing amounts of rabies." The lack of water and the prevailing disregard for all forms of animal suffering largely contributed to this situation.

The municipality in collaboration with the Internal Affairs Office made efforts to fight rabies. In 1891 the municipality contributed $200 \mathrm{Dr}$ for the founding of a hospital for rabies in Athens and 200 more for the training of a specialist doctor in the Institut Pasteur in Athens. It also collected affidavits from the Internal Affairs Office concerning the extermination of stray dogs, but a newspaper of the time still considered these measures to be inadequate for the prevention of the disease. Twice or three times the municipality paid the costs for the treatment of two rabies patients in France ${ }^{48}$. The quarantine measure was often imposed on the newborn state, which many times followed the practices of other European states (except Britain) concerning the fight against diseases carried by foreign ships. The quarantines lasted $3-5$ days, but

47 Kotea 1997, ch. 6, esp. 132-145. See also all the articles in the local newspaper Pronia, 1901 and 1902, dedicated to the hygiene problems of Piraeus.

48 Municipal Council, 'Report of the Accounts of the Municipality of Piraeus, for the Year 1874' (1875); see also the folders 1891 and 1899 in the Historical Archives of the Municipality of Piraeus (HAMP). For public health problems and measures taken by the municipality see the report by the Consul, Masxe 1896, Sphaira 1894a; Sphaira 1891a; Pronia 1900b. 
in cases of major epidemics,11-21 days. The hygiene and port authorities were responsible for the quarantines. The upper classes had the option of renting specific places and creating 'a middle class family home' in the quarantine area. The quarantines originally took place in the St George Lazaretto 'Teratsini', but it seems that later on this place was also used as a hostel for people arriving from epidemic-stricken areas before they were transferred to Delos for quarantine.

The quarantines were an effective measure for maintaining public health but at the same time they could be ruinous for the economy. Another measure used for prevention was disinfection. In 1893 in the city of Piraeus, during a cholera epidemic, the municipality followed the advice given by ten city doctors invited by the municipality. The city was divided into four parts, each supervised by a doctor, the police constable and the mayor. The municipality was disinfecting houses free of charge. In contrast to other European cities, where permanent committees existed for health matters, the Municipality occasionally created temporary health committees, consisting of municipal and private doctors from the city, in order to react to urgent epidemics.

The great 1905 smallpox epidemic forced the Municipal Council to reconsider the building of a disinfectionary. At first it was suggested that a temporary one should operate in the municipal slaughterhouses, but later on a permanent accommodation for the disinfectionary was decided on ${ }^{49}$. Table 6 shows that the municipality was using a considerable amount of its budget for disinfection. Most of the expenses, however, were used for the hospitals. The very low percentage of the total budget in the last benchmark year has to do with a loan taken by the new mayor to cover the municipal debt. As a result the budget rose considerably. In the following year the percentage returned to just under $5 \%$.

\section{Hospitals and ambulatory medical care}

Efforts to build a small civil hospital began in 1836. Although there was no civil hospital, some of the army's and navy's health needs were taken care of in the house of G. Thettalos, which was granted to the municipality in 1842. Three years later, a group of citizens asked for the removal of the patients from this place, where 5-10 patients could be treated, because clinics should operate outside the city limits. Other patient care was practised in private houses and a special hospital for prostitutes. This Hospital for Common

49 See the articles concerning the measures against the smallpox epidemic in Sphaira 1893a and b; Sphaira 1895a; Pronia 1900a. See also Municipal Council, 'Decrees', 1906-1909. 
Women, though supervised by the municipality, was controlled by the 'Royal County of Attica and Viotia ${ }^{50}$.

Table 6. The expenses of the Piraeus Municipal Council concerning medical and hygienic care (in drachmas).

\begin{tabular}{lrrrrr}
\hline & 1870 & 1880 & 1890 & 1900 & 1910 \\
\hline municipal doctor(s) & 1200 & - & 3600 & - & 4560 \\
\hline municipal midwife/-wives & 2250 & 1336 & - & - & - \\
\hline oculist for the hospital & - & - & - & 1800 & - \\
\hline disinfection and medical care & 1930 & - & 1960 & 3000 & 18980 \\
\hline Zanion Civil Hospital & - & 15231 & 30000 & 44000 & 60000 \\
\hline Medical Society of Piraeus & - & - & - & 1200 & - \\
\hline rabies (Pabouki Clinic or other) & - & - & 1970 & 800 & 2000 \\
\hline first aid station & - & - & - & - & 2000 \\
\hline total & 5380 & 16567 & 37530 & 50800 & 87450 \\
\hline percentage of the total budget & 3.3 & 3.6 & 5.7 & 3.3 & 4.8 \\
\hline revenues Zanion Civil Hospital & - & 13560 & 28350 & 75740 & 71729 \\
(except municipality subsidies) & & & & & \\
\hline
\end{tabular}

Source: Municipal accounts.

The first hospital in Piraeus was constructed on a piece of land granted by the state, mainly with a donation from the philanthropist N. Zanis. The first part of the Zanion Nosocomion was ready in 1873. On the upper floor of this hospital were 16 heated rooms for patients and in the basement another 16 rooms for kitchens, heating and pharmacy. According to the hospital rules there was no discrimination with regard to origin, ethnic group, religion, nationality or profession. Indigents were treated free of charge and wealthy citizens were charged. There was a clientele system between the mayor and the poorer citizens who were granted written permits for free health care, admission and treatment in the city hospital. Piraeus newspapers from the late nineteenth century report a lack of free beds and the shutting of the hospital doors to the indigent by the hospital authorities. By 1874 already, the crews of the Russian, Italian, French and Greek navies comprised the largest segment of patients who were treated there, which explains the international character of the hospital.

50 Spiliotopoulos 1939, 19-20. See also all the discussions of the Municipal Council concerning medical care before the foundation of the Zanion Hospital, in: the Municipal Council, 'Minutes of Meetings', 1854,1865-1867. The Folders, 1842,1856B, 1868A, 1879, in the HAMP; cf. Hronografos 1954. 
The hospital was scheduled to begin operating with 24 beds. However, owing to increased demands predicted for the following years, the number rose to 40 (30 free beds for male citizens, 6 for women and 4 for paying patients). In the first years of the Hospital's history, the capacity of Zanion more than covered the needs of the city because patients preferred to be cared for at home. Moreover, at least until the establishment of the Evangelismos Hospital in Athens in 1884, hospital care was considered a reproach of the patient's family ${ }^{51}$. In 1877 the ratio between free and paying patients was 87:13. In addition to the hospital care, the hospital had a pharmacy which provided free medication to inpatients and outpatients who were poor ${ }^{52}$. The hospital evolved into a political tool, which no longer provided free services only to the poor but also to the wealthy and thus was accused at the end of the nineteenth century of being a political branch of the municipality to gather votes.

In 1878 Zanion received the protection of the Queen of Greece, Olga. However, in her attempt to nominate doctors, she discovered that she could not effectively interfere in the management of the hospital. Therefore, she withdrew her support and in 1902 she founded the Russian Hospital in Piraeus $^{53}$. In 1885 Zanion was divided into two branches: pathological and surgical. Due to cash flow problems the hospital's situation did not improve and it looked more like a shelter for the homeless than a hospital. Consequently, in 1888 the mayor of Piraeus took drastic measures for improvement which, however, only affected paying customers and failed to improve the quality of services to non-paying patients. Despite these failures, the efforts for improvement continued and in 1896, with a donation from the philanthropist Salepas and a contribution from the municipality, the construction of a new wing for the surgical department was undertaken.

After the industrial revolution, a period of professional specialisation followed and more departments were added to the two already existing departments of pathology and surgery. N. Ekonomopoulos, an oculist from Athens who had studied in Paris, had directed the eye clinic in Zanion since 1893. He treated 2764 people between October 1893 and July 1896. Also, a small department was reported for diseases of the nose and larynx. The role of the external clinics (eye clinic, surgery, pathology and syphilis clinic) was very important. Free medical advice, medication and bandage changes were offered there. A large number of minor surgical operations also took place:

51 Andrianakos 1933, 40.

52 The hospital's pharmacy in Lyon had also many functions in 1830, Faure 1982, 169-172.

53 See the reports concerning the budgets of the Zanion Hospital, 1874-1879. See also the details on the Russian Hospital, Kotanov 1905, 57-58. 
2376 in 1910, 2104 in 1909 and 2042 in $1908^{54}$. At the beginning of the twentieth century, the hospital, which at that time had 75 beds, had a low death ratio. According to the hospital report of 1910 of the total number of inpatients, $69(5.9 \%)$ died. The surgical department seems to have been excellent, according to the testimony of a councilman of the opposition, and the fact that the number of operations increased. But the general image and perception of the hospital were poor, because many patients preferred the Russian Hospital. From the point of cost-effectiveness, the hospital operated efficiently. In 1910 it spent 85000 drachmas for 1154 inpatients and 33816 outpatients, while the Evangelismos Hospital spent 350000 drachmas for 2221 inpatients ${ }^{55}$. During the nineteenth and the early twentieth centuries there were strong interdependencies, which linked the Municipal Council, the society and the scientific and auxiliary personnel. The Municipal Council elected the hospital society, the hospital society had authority only over the enlistment of the senior doctors (who were often friends), and the senior doctors appointed the lower medical staff. The hospital manager was elected from the hospital society and appointed the lower administrative staff. All of the above-mentioned authorities were political allies of the Municipal Council ${ }^{56}$.

The expenses for the construction, the equipment and the operation were paid by legacies, contributions from philanthropists and, after the end of the nineteenth century, municipal subsidies. The bourgeoisie of Piraeus tried to improve public health in the city in two ways: firstly through its political control of the Municipal Council and its control of the society of the hospital, and secondly through financial contributions and voluntary free medical services given by the doctors (who were members of the upper class). This interest on the part of the bourgeoisie was not only motivated by purely charitable motives as taught by the Greek Orthodox Church. A number of articles in an economic review of the late nineteenth century indicate that good public health was considered to make sense economically because it improved the output and quality of the labour force. The philanthropists had also social motivations, free health care was used to reduce the disparity between members of the local population thus reducing the risks of revolts and fights between them. Finally, some members of the bourgeoisie used

54 Municipal Council, 'Minutes of the meetings', 11th November 1911.

55 Accounts of the Municipality of Piraeus; Proceedings of the Municipal Council, vol. 1911-1913, session 22.11.1911; cf. Report of the hospital's practitioner D. N. Hoidas, in HAMP folder 1895.

56 Municipal Council, 'Minutes of the meetings', 15th October 1910. See also the new Regulation of the Zanion Civil Hospital in the Municipal Council, 'Minutes of the Meetings', 22nd August 1900, 178-197. See also Sphaira 1895b; Sphaira 1895e. 
donations and charitable contributions for their own personal gratification, thus obtaining free publicity through the local press and often gaining honorary positions and local power ${ }^{57}$.

The Municipal Hospital's regulations prohibited the treatment of patients suffering from contagious diseases. Only in special cases could these patients be treated in the hospital's basement. In Kantharos, the area where the city lazaretto was situated, a very basic hospital for smallpox patients seems to have been operating since 1880. Its deficiencies were tragic: inefficient treatment, terrible diet and, most of all, deficient medical care due to the distance of the hospital from the centre of the city of Piraeus. This special hospital operated for a decade as a branch of the Zanion.

By the end of the century, the need for a proper hospital for contagious diseases increased. Yet it seems that, for a certain period, patients were transferred to Athens to be treated in a hospital (Pangrati). Meanwhile the municipality pressed the state to reorganise the hospital. Finally, in 1899, the hospital reopened with the aid of the ministry. Despite all the efforts made to improve the situation, the conditions in the 'Smallpox hospital' in subsequent years were considered bad ${ }^{58}$.

In the 1890s, in the new City of Piraeus Home for the Aged, a Diphtheria Patients' Hospital was also operating. A philanthropist lady of the Piraean society had granted a disinfection furnace to this hospital. But, as we can see in the Piraean newspapers, until 1895 at least no one was treated at this hospital, which was apparently founded for party political purposes ${ }^{59}$.

\section{The results}

The end of the nineteenth century brought better health care conditions and service quality (new methods and more departments) to the municipal hospital. If there was no hospital for handling a special disease or treatment, the indigent population was sent to Athens or to other cities, and even abroad at the expense of the municipality. The wealthy citizens had access to private rooms in the Zanion Hospital as well as in the Russian Hospital, and to the 'Polycliniki' private clinic, which did not function properly due to insufficient funds. There were many private doctors who advertised in the local press. Often these were the same doctors who worked for the hospital.

57 Ikonomiki Epitheorisis 1873,355-359; Ikonomiki Epitheorisis 1888a, 447-457; cf. Ikonomiki Epitheorisis 1888b, 93-97; Theodorou 1992, 71-90; cf. Sapounaki-Dracaki 1986b, 412-413.

58 See the folders 1886-1887 and 1892 in the HAMP and Municipal Council, 454 'Decrees',23rd April 1899. See also all the articles in Sphaira 1891b; Pronia 1905.

59 Sphaira 1894b. 
The statistics of the death rates do not adequately reflect the actual situation (see table 7). They are biased by the fact that at the beginning of the twentieth century many Greek emigrants who had been diagnosed as terminally ill with tuberculosis returned to Piraeus from the United States for treatment at the seaside, which was considered healthy ${ }^{60}$.

Table 7. Number of deaths and death rates in Piraeus.

\begin{tabular}{lllll}
\hline & population & deaths & death rates & death rates without tuberculosis \\
\hline 1870 & 11047 & 213 & 19.3 & 17.0 \\
\hline 1879 & 21618 & 535 & $24.8^{*}$ & 21.8 \\
\hline 1889 & 34569 & 787 & 22.8 & 19.6 \\
\hline 1895 & 51020 & 1270 & 24.9 & 21.3 \\
\hline 1907 & 74580 & 1752 & 23.5 & 20.6
\end{tabular}

Sources: Register Office: Register of Deaths 1866-1883, Registers of weddings, births and deaths 1870-1908. * 25.4 see Pronia, 1889.

Because of the lack of special sanatoriums and also because of the costs of the lengthy treatment of this disease, the common practice was treatment at home. In Piraeus at the end of the nineteenth century, about $25 \%$ of the patients who were nursed by their poor families were suffering from tuberculosis ${ }^{61}$. In many cases, these families became infected too. Thus, while in other European countries the death rate due to tuberculosis was falling or stagnating, in Greece, and especially in Piraeus, the rate was increasing. Between 1866 and $1879,11 \%$ of all deaths were diagnosed as resulting from tuberculosis; between 1891 and 1898 the rate was $13 \%$, and between 1899 and $1908,15.6 \%{ }^{62}$. The actual numbers, however, may have been even worse. This was due to two facts. Firstly, many cases were not reported because of the common notion in these times that it was shameful for a family to have a tuberculosis patient, and secondly, many cases were wrongly diagnosed as simple lung infections while they were in fact tuberculosis ${ }^{63}$.

When we take into account the deaths due to tuberculosis of nonresidents at the end of the period, using the rare official data from the population statistics, we may conclude that there was no improvement in public health

60 See Foustanos about the destructive effects of tuberculosis in: Zaharias 1994, 81. The measures taken against tuberculosis were more efficient in Holland than in Greece. When the Queen donated 40000 francs and a property in order to build a hospital for the poor patients suffering from tuberculosis, etc. (see Patrikios 1902, 7), there were already 10 in the Netherlands.

61 Patrikios 1917, 14.

62 Patrikios 1906, 14-16; Patrikios 1917, 26-27; see also Kardamatis on the mortality from tuberculosis in Greece in: Zaharias 1994, 83.

63 Patrikios 1906, 16; Zaharias 1994, 80-88. 
at the end of the nineteenth century. Still, real wages were slightly rising in that time, especially for employees and skilled labourers ${ }^{64}$. For employees of the municipality of Piraeus, even if they were unskilled, there was an overall rise in real income ${ }^{65}$. The average nominal wages in the factories, however, remained rather stable ${ }^{66}$, as did the prices of the main foodstuffs ${ }^{67}$. So there must be other explanations for the relatively high level of mortality in Piraeus. A closer comparison with Groningen, where the death rate showed a considerable fall, may give some insights into this matter.

\section{Groningen and Piraeus compared}

Given the limited scope of this article, a comparison between Groningen and Piraeus can only have an exploratory character. A more precise comparison would have to include the occupational and social structure of both cities. For Piraeus, however, these data are not available ${ }^{68}$. One problem is that the Turkish occupation had levelled Greek society. It was only after the 1821 Greek War of Independence that a bourgeoisie emerged from the minor tradesmen, minor entrepreneurs and employees. Starting from 1835 in Piraeus, according to the taxation lists, three groups emerged: the upper stratum, which was composed of very rich landowners and entrepreneurs, usually Greeks from the diaspora; the middle stratum consisting of artisans and tradesmen (representing the largest group of the working population after 1870), and the lower stratum which was mainly composed of servants. The first two categories were initially not clearly separated, but by around 1850 they began to be distinctly different. In 1853, the upper stratum represented $5.65 \%$ of the working population. This was the elite of Piraeus which can be compared with the Groningen elite, which consisted of 2-4\% of the population ${ }^{69}$. The working class in Piraeus also manifested itself much later as a pressure group than in Groningen due to the large waves of migration.

It seems clear that, by the second half of the nineteenth century, the elite in both Piraeus and Groningen was determining policy concerning public health affairs. The motives of both elites were primarily those which Abram

64 See for the case of the employees of the National Bank of Greece: Pizanias 1985.

65 Sapounaki-Dracaki 1986a, 72-73.

66 Agriantoni 1986, 289-290.

67 See Pizanias 1985, 69; Pizanias/Mitrophanis 1991; cf. Sapounaki-Dracaki 1994. The prices of the main food articles: bread, olive oil, meat, beans, wine were in 1870-1879 respectively $0.39,1.09,1.08,0.32,0.70 \mathrm{Dr}$ per $\mathrm{kg}$. In $1890-1899$ this was $0.44,1.11,1.16,0.44,0.46$. Wine consumption therefore rose considerably.

68 For Groningen, see note 12.

69 See note 12 and Tsokopoulos 1984, 96-110. 
de Swaan has pointed out in general terms in his analysis of public health care as a process of collectivisation: social peace, fear of contagious diseases and self-interest ${ }^{70}$. Self-interest is described as the process of growing unwillingness of the elite to accept free riders. Collectivisation is intended to increase the financial participation of all members of the elite and will result in a decreasing need for philanthropy by individuals.

Seen from this point of view, it seems that in Groningen collectivisation was more advanced than in Piraeus because of the almost complete lack of philanthropy. As has been mentioned above, there was only one case, whereas in Piraeus almost all of the hospitals were founded by philanthropists. However, philanthropy in Piraeus had a political character - it was manipulated by rich individuals in order to organise a political 'clientele'. In Groningen and in other Dutch cities, such a thing was impossible. New rich industrialists and other 'parvenus' were considered suspect by the old local elites, which mainly consisted of high civil servants and traditional manufacturers and salesmen. They did not allow these newcomers to play a prominent role on the political scene ${ }^{71}$. Traditionally, this old elite also practised philanthropy, but on a more modest scale and in an increasingly collective way. In the period under review, these activities mainly consisted of subsidising building companies for housing for the lower middle class and the upper working class. However, politics were not completely absent from the organisation of public health care in Groningen. The foundation of a Protestant and a Roman Catholic hospital marked the typical Dutch process of cleavage, the organisation of the population along denominational lines ${ }^{72}$.

In neither city was public health care a great priority for the municipal government. The share of the municipal budget for public health was rather low in both cities and, after 1900, it was even extremely low. In both cities, policy had an ad hoc character, epidemics were the most important catalysts. There was, however, one important difference: in Piraeus the public health policy was exclusively focused on hospital care, whereas in Groningen there was a twofold policy which not only pivoted on hospital care but also on the promotion of public hygiene. Moreover, in Piraeus there was a policy of isolating patients, suffering from contagious diseases, to remote places, whereas in Groningen these patients were integrated at an early stage in separate departments of the general hospital. The priority of public hygiene in Groningen was induced by the hygienists, a group of doctors which had no counterpart in Piraeus.

70 De Swaan 1988.

71 Kooij 1992.

72 See for instance, Lijphart 1968. 
Comparing both cities, the effects of these extra efforts on the part of the hygienists seem to have been obvious. In the years for which we have data on both cities, the death rates in Piraeus remained rather stable while in Groningen they fell (table 8).

Table 8. Death rates in Groningen and Piraeus compared.

\begin{tabular}{lllll}
\hline & \multicolumn{2}{l}{ Groningen } & Piraeus \\
\cline { 2 - 5 } & total & tuberculosis & total & tuberculosis \\
\hline 1870 & 31.9 & 3.29 & 19.3 & 2.26 \\
\hline 1879 & 23.9 & 3.10 & 24.8 & 2.98 \\
\hline 1889 & 18.6 & 2.04 & 22.8 & 3.18 \\
\hline 1896 & 14.7 & 2.35 & 24.9 & 3.54 \\
\hline 1907 & 13.1 & 1.57 & 23.5 & 2.93 \\
\hline
\end{tabular}

Sources: Groningen Archives: Deaths Registers 1870-1907. Sources table 4 and table 7.

The decrease with respect to Groningen is rather spectacular but we have to keep in mind that there was a smallpox epidemic in 1870/71, which substantially increased the number of deaths per thousand in that year. The influence of tuberculosis on the death rate in Piraeus seems to have been less distinctive as some writers suggest. In Groningen this disease was also an important killer, especially among unskilled workers, but its share was declining.

Unfortunately, there are no data available to compare the other causes of death in both cities over the whole period. For Piraeus we only have these data for the period 1866-1879. A problem is that, in a quarter of all cases, the cause of death is unknown. When we eliminate these numbers, a comparison of Groningen and Piraeus shows only slight differences (table 9).

Table 9. Causes of death in Groningen (1867-1874) and Piraeus (1866-1879) (\%).

\begin{tabular}{lcclll}
\hline & Groningen & Piraeus & Groningen & Piraeus \\
\hline contagious diseases & 14 & 15 & tuberculosis & 12 & 15 \\
\hline cancer & 4 & 1 & nervous system & 12 & 11 \\
\hline $\begin{array}{l}\text { heart and vascular } \\
\text { diseases }\end{array}$ & 2 & 8 & respiratory organs & 21 & 25 \\
\hline digestive organs & 15 & 19 & urogenital organs & 4 & 1 \\
\hline $\begin{array}{l}\text { pregnancy and } \\
\text { childbirth }\end{array}$ & 1 & 1 & stillbirth & 15 & 5 \\
\hline
\end{tabular}

Sources: see tables 4 and 7. 
The data for both cities are hardly comparable. Diagnostics and the compilation of statistics seem to have taken place in different ways, as 'stillbirth' and the rather high percentage of heart disease in Piraeus indicate. Nevertheless, it is noteworthy that, in Piraeus, the number of deaths due to diseases of the respiratory and digestive organs was relatively higher. Since these diseases were common among children, a comparison of infant and child mortality may shed some light on this matter (table 10).

Table 10. Infant and child mortality in Groningen and Piraeus (percentage of all deaths).

\begin{tabular}{lllllllll}
\hline & & & & & \multicolumn{2}{c}{ percentage of total population } \\
\cline { 5 - 9 } & Groningen & \multicolumn{2}{l}{ Piraeus } & & Groningen & \multicolumn{2}{c}{ Piraeus } \\
\hline & $0-1$ & $1-5$ & $0-1$ & $1-5$ & $0-1$ & $1-5$ & $0-1$ & $1-5$ \\
\hline $1860 / 66$ & - & - & 28 & 15 & - & - & - & - \\
\hline 1870 & - & - & 26 & 17 & - & - & 1.4 & 9.6 \\
\hline $1875 / 79 *$ & 28 & 14 & 29 & 15 & 3.2 & 10.1 & - & - \\
\hline $1910 / 11^{* *}$ & 15 & 8 & 21 & 13 & 2.4 & 8.5 & 3.2 & 6.7 \\
\hline
\end{tabular}

Sources: Groningen: Deaths Registers, Censuses; Piraeus: Tsokopoulos 1984, 94; Register Office: Register of Deaths 1866-1883, Registers of Weddings, births and deaths 1870-1908; cf. Register of the Cemetery Anastasis (1910-1911).

* age distribution 1.1.1880.

** age distribution Groningen 1.1.1910, Piraeus 1907.

As table 10 shows, there was hardly any difference between Groningen and Piraeus regarding infant and child mortality in 1875-1879. Therefore we may conclude that, in Piraeus, a number of stillbirths are registered in other categories of table 9 , especially diseases of the respiratory and digestive organs. However, around the turn of the century, a fall in mortality among children manifests itself in Groningen, whereas Piraeus remains on a higher level. We are not informed about possible differences in ways of feeding the children, although there are indications that, in both cities, breast feeding was a common practice. But what is quite clear is the difference in public and private hygiene. Thanks to the efforts of the hygienists, and the opportunity to sell garbage and faeces for a good price, Groningen was described at that time as one of the cleanest cities in the Netherlands.

In Piraeus, however, although there were laws to improve public health, the traditions of the citizens ignored their intention. This is why the British consul in Piraeus reported "an absolute lack of any cleaning of the streets and very primitive scavering arrangements which contribute greatly to the spread of all forms of diseases and that public health in Athens and Piraeus leave much to be desired, the principal causes of which are bad drainage 
and water supply" ${ }^{\prime 3}$. In our view, this difference in mentality concerning public and private hygiene, even though it was only partly reflected in public expenditure, seems to have been a major reason for the difference in mortality in both cities. Of course, this does not exclude other reasons mentioned above. However, to fix their relative importance, we need more accurate data in order to be able to compare the standards of living of the different social groups in both cities in relation to their relative sizes. We also need to know more about access to medical care. The threshold for receiving health care seems to have been lower in Piraeus than in Groningen. In Piraeus it was relatively easy for the lower classes to be admitted to hospital. Whereas in Piraeus this was a way of mobilising potential voters, in Groningen the Poor Law administrators tried to avoid admission to hospital as long as possible because of the high costs concerned, which were about ten times higher per patient as ambulatory medical care. But what percentage of ill people actually went to a hospital, or, in the case of Groningen, to doctors for the poor? And how did the middle classes behave?

A final point of interest is that, in Greece, the state remained at a greater distance than it did in the Netherlands. The municipality of Piraeus received no subsidy at all for public health care, whereas in Groningen there were some subsidies, not only for hospitals but also for poor relief. Anyway, our tale of two cities may have shown, up until now, that a corresponding national legal framework on the local level gave rise to a rather different actual policy which, because of different traditions in medicalisation and the implementation of public hygiene, had diverging results in terms of the death ratios.

\section{Sources}

Groningen Archives

Bevolkingsregisters (Registers of the population), 1870-1914

Burgerlijke stand. Overlijdensregisters (Death Registers)

Handschriftenverzameling (Collection of handwritings)

Overlijdensbriefjes (Death Forms)

Raadsverslagen (Minutes of the meetings of the Municipal Council), 1870-1914

Registers van de hoofdelijke omslag (Registers of the Poll Tax)

Statistiek van de sterfte (Statistics of deaths)

Verslag van den toestand der gemeente Groningen, 1870-1914

Verslagen van de Vereeniging ter bevordering van de Volksgezondheid (Minutes of the Association for Public Health)

Archives of the Groningen Academic Hospital

Patiëntenregisters (Registers of Patients), 1870-1910

73 McDonnell 1907. 
Historical archives of the Municipality of Piraeus (HAMP)

Budgets of Zanion Civil Hospital (1874-1914)

Folders (1835-1914)

Minutes of the meeting of the Municipal Council (1850-1914)

Municipal Council decrees (1906-1909)

Reports of Accounts (1865-1914)

Archives of the Register Office of Piraeus

Register of Deaths (1866-1883)

Registers of Weddings, births and deaths (1870-1908)

Register of the Cemetery Anastasis (1910-1911)

\section{Literature}

Agriantoni, Christina, The Outset of Industrialization in Greece in the 19th Century (Athens 1986)

- "Economy and industrialization in 19th century Greece", in: Vassilis Kremmydas (ed.), Introduction to modern Greek History 19th-20th century (Athens 1999) 145-177

Alexakis, G., Complete Guide of Piraeus 1906-1907 (Piraeus 1906)

Anderson, Michael, "Population change in north-western Europe, 1750-1850", in: Michael Anderson (ed.), British population history. From the Black Death to the present day (Cambridge 1996) 191-281

Andrianakos, Tryfon, Medicine in modern Greece 1800-1930 (Thessaloniki 1933)

Baron, Minie/Pim Kooij, „Anamnese van de gezondheidszorg in Groningen. De negentiende eeuw", in: F. Huisman (ed.), Gezond weer op in Groningen. Gezondheidszorg en medisch beroep 1500-1900 (Groningen 1993) 67-92

Bergink, A. H., Samuel Senior Coronel. Zijn betekenis voor de sociale geneeskunde in Nederland (Assen 1960)

Chouliarakis, M., The Evolution of the Geography, Administration and Population of Greece, 1821-1971, vol. 1 (Athens 1974)

De Swaan, A., In Care of the State: Health Care, Education and Welfare in Europe and the USA in the modern Era (Cambridge 1988)

Dumons, Bruno/Gilles Pollet/Pierre-Yves Saunier, Les élites municipales sous la III ${ }^{e}$ République. Des villes du sud-est de la France (Paris 1998)

Faure, Olivier, Genèse de l'hôpital moderne: les hospices civils de Lyon de 1802 à 1845 (Lyon 1982)

Flogaitis, Theodoros, Guide for the Public and Municipal Employees (Athens 1890)

Hietala, Marjatta, Services and urbanization at the turn of the century (Helsinki 1987)

Holland, Walter/Roger Detels/George Knox (eds), Oxford Textbook of Public Health, vol. 1 (Oxford 1984)

Houwaart, Eddy S., De hygiënisten. Artsen, staat en volksgezondheid in Nederland 1840-1890 (Groningen 1991)

Hronografos, 21st January 1954

Huisman, Frank, Stadsbelang en standsbesef. Gezondheidszorg en medisch beroep in Groningen 1500-1730 (Rotterdam 1992)

Ikonomiki Epitheorisis, "Public hygiene", 8 (1873) 355-359

Ikonomiki Epitheorisis, "The health care system of the municipalities", 142 (1888a) 447-458

Ikonomiki Epitheorisis, "Health and life from the economical point of view",134 (1888b) 93-113

Kalamitsis, Nikolaos, The Industry of Piraeus (Piraeus 1960)

Kambouroglou, P., History of Piraeus 1833-1882 (Athens 1883)

Kooij, Pim, Groningen 1870-1914. Sociale verandering en economische ontwikkeling in een regionaal centrum (Assen/Maastricht 1987)

- "Fingerprints of an urban elite: the case of a Dutch city in the nineteenth century", in: Diederiks, Herman/Paul Hohenberg/Michael Wagenaar (eds), The Visible Hand and the Fortune of Cities. Economic Policy in Europe since the Late Middle Ages (Leicester 1992) $102-124$ 
- "Groningen: central place and peripheral city",in:Kooij,Pim/Piet Pellenbarg (eds), Regional Capitals. Past, Present, Prospects (Assen 1994) 37-63

Korasidou, Maria, When Illness Threatens. Supervision and monitoring of the health of the population of Greece in the 19th century (Athens 2002)

Kotanov, A., "The Russian Hospital in Piraeus", Archeia Iatrikis 2 (1905) 57-58 [Greek translation from the Russian]

Kotea, Marianthi, The Industrial Zone of Piraeus, 1860-1900 (Athens 1997)

Kousis, A. P., The Scientific Work of the Athens Medical Society, 1835-1885 (Athens 1927)

- The First Principles of Hygienic Policy and Organization of Public Health in Greece (Athens 1947)

Lijphart, A., The Politics of Accommodation. Pluralism and Democracy in the Netherlands (Berkeley 1968)

Mastroyannis, J., The History of Social Welfare in Modern Greece, 1821-1960 (Athens 1960)

Masxe, "Piraeus Greece 1895", in: Foreign Office Annual Series Diplomatic and Consular Reports on the trade and finance 1694 (Piraeus 1896) 17-18

McDonnell, E. R., "Trade and Agriculture of Piraeus and District, 1906", in: Foreign Office Annual Series Diplomatic and Consular Reports on the trade and finance 3785 (Piraeus 1907)

Ministry of Interior, Statistics of Greece: Population 1861 (Athens 1862, repr. 1991)

Mpoukas, M., Commercial Agricultural and Historical Guide of the year 1875 (Athens 1875)

Patrikios, V., Policy of the Greek Society against Tuberculosis (Athens 1902)

- The Evolution of Tuberculosis in Greece 1890-1905 (Athens 1906)

- Report on the Death Rates of Tuberculosis in Greece (Athens 1917)

Pizanias, Petros, Wages and Incomes in Greece 1842-1923 (Athens 1985)

Pizanias, Petros/Georgios Mitrophanis, Mouvements des prix en Grèce, XIX $X^{e}$ siècle début du XIX ${ }^{e}$ (Athens 1991)

Powel, Martin, "Did politics matter? Municipal public health expenditure in the 1930s", Urban History 22 (1995) 360-380

Price, D. G./A. M. Blair, The Changing Geography of the Service Sector (London 1989)

Pronia, various numbers

Querido, A., Een eeuw staatstoezicht op de volksgezondheid (Den Haag 1965)

Rigatos, G. A., Papers from the Medical History of Athens (Athens 1991)

Sapounaki-Dracaki, Lydia, Le mouvement des salaires municipaux dans la ville du Pirée au XIX ${ }^{e}$ siècle (Master's thesis, Paris I University 1986a)

- "The evolution of the education of the labour class in Piraeus in the 19th Century", Historica 6 (1986b) 387-415

- "Price and quality of bread: State intervention and Municipal Policy in the Urban Centers of Greece (1835-1900)", in: Cultural Foundation ETVA (ed.), From grain to bread (Volos 1994) $278-291$

- «Genèse et évolution des règles et des normes dans la bureaucratie municipale du Pirée au $19^{\circ}$ siècle», Revue de décentralisation d'administration locale et de développement régional 15 (1999) 25-37

Savas, K./A. P. Kousis, "Athens: A medical perspective”, in: Drandakis (ed.): Megali Elliniki Egyklopaidia, 2 vol. (Athens cir. 1930) 252-260

Sphaira, various numbers

Spiliotopoulos, D. Th., Piraeus and the Mayors of the first Centenary (Piraeus 1939)

Stratingh, S. E., Groningen als woonplaats beschouwd (Groningen 1858)

Szreter,Simon, "The importance of social intervention in Britain's mortality decline c. 1850:1914: a re-interpretation of the role of public health", Social History of Medicine 1 (1988) 1-37

Tammeling, Bart P., RKZ Groningen (Groningen 1979)

- 100 jaar Diakonessenhuis Groningen (Groningen 1987)

Theodorou, V., "Philanthropy and city: Piraeus 1875", Mnimon 14 (1992) 71-90

Tonckens, N., „Een eeuw ziekenhuis aan de Munnikeholm”, in: Groninger Volksalmanak (1954) 6-54, and (1955) 149-159

Tsokopoulos, V., Piraeus, 1835-1870 (Athens 1984)

Tuin, Bert/Frank Venema, Groningen op recept. Twee eeuwen farmacie 1782-1982 (Groningen 1982)

Van der Woude, Rolf/Willy van der Schuit, Oude tradities, nieuwe ambities. 200 jaar Academisch Ziekenhuis Groningen (Groningen 1997) 
Van Lieburg, Marius Jan, Het Coolsingelziekenhuis te Rotterdam (1839-1900). De ontwikkeling van een stedelijk ziekenhuis in de 19e eeuw (Amsterdam 1986)

Van Zanden, Jan Luiten, The economic development of the Netherlands since 1870 (Cheltenham 1996)

Vögele, Jörg, Urban Mortality Change in England and Germany, 1870-1913 (Liverpool 1998)

Zaharias, K., "Tuberculosis, future past and present", in: Proceedings of the Panhellenic Conference (Athens 1994) 80-88 